\section{ELAEIS GUINEENSIS LEAVES EXTRACTS AS ECO-FRIENDLY CORROSION INHIBITOR FOR MILD STEEL IN} HYDROCHLORIC ACID

Mohammad Ali Asaada, Mohammad Ismaila*, Nur Hafizah A. Khalida, Ghasan Fahim Huseiena, Pandian Bothi Rajab

aDepartment of Civil Engineering, Universiti Teknologi Malaysia, 81310 UTM Johor Bahru, Johor, Malaysia

bSchool of Chemical Science, Universiti Sains Malaysia, 11800 USM, Pulau Pinang, Penang, Malaysia
Article history

Received

13 June 2017

Received in revised form

12 June 2018

Accepted

30 June 2018

Published online

5 October 2018

*Corresponding author mohammad@utm.my

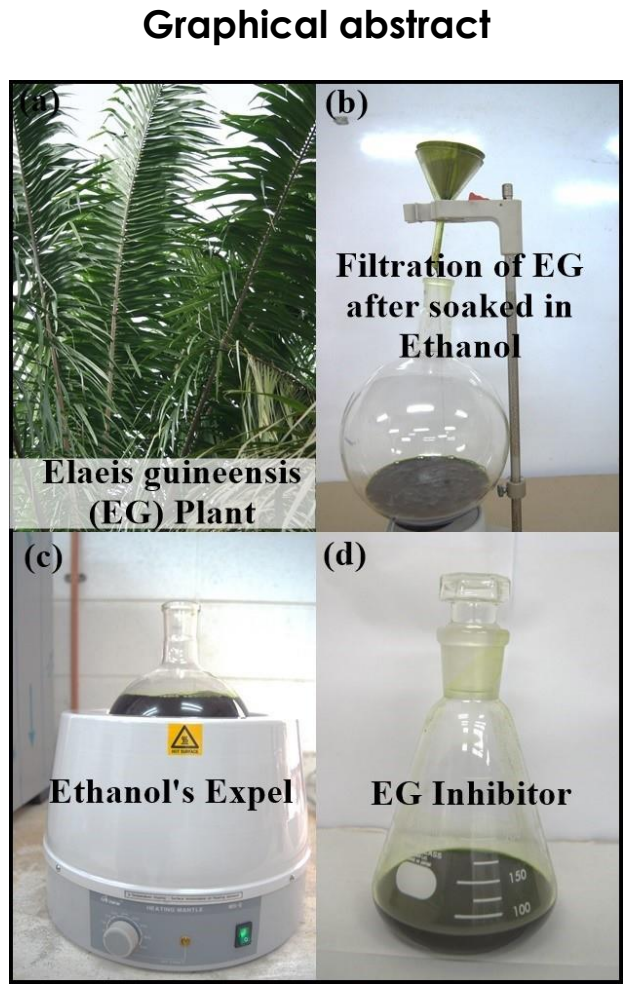

\begin{abstract}
This manuscript presents a study on a green corrosion inhibitor extracted from Elaeis guineensis (EG) leaves for mild steel (MS) exposed to acidic condition. Weight loss measurement was conducted at various temperatures to investigate the corrosion inhibitive behaviour of the aqueous extract in $1 \mathrm{M} \mathrm{HCl}$ solution. Results demonstrated that both inhibition efficiency $(n \%)$ and surface coverage $(\theta)$ had increased with increasing inhibitor concentration, but decreased with increasing temperature. After immersion for $72 \mathrm{~h}$, the inhibition efficiency were between $60.48 \%$ at $319 \mathrm{~K}$ and $73.81 \%$ at $298 \mathrm{~K}$. Adsorption of extract onto the MS surface was shown to obey Langmuir's adsorption isotherm while the free energy value ( $\Delta$ Gads) indicated that the adsorption was characteristic of physisorption. Formation of a protective film onto the metal surface was substantiated by SEM and EDX analyses. The study demonstrated that EG leaves is a potential metal corrosion inhibitor in acidic condition.
\end{abstract}

Keywords: Mild steel, Elaeis guineensis, corrosion inhibition, weight loss, SEM

\begin{abstract}
Abstrak
Manuskrip ini membincangkan kajian mengenai suatu perencat kakisan hijau yang diekstrak daripada daun Elaeis guineensis (EG) untuk keluli kekuatan sederhana (MS) yang terdedah kepada suasana asidik. Ukuran pengurangan berat besi telah dijalankan pada pelbagai suhu untuk menyiasat sifat perencatan kakisan ekstrak akueus tersebut dalam $1 \mathrm{M} \mathrm{HCl}$. Keputusan menunjukkan bahawa kedua-dua kecekapan perencatan $(\eta \%)$ dan liputan permukaan $(\theta)$ telah meningkat dengan peningkatan dalam kepekatan perencat, tetapi menurun dengan peningkatan suhu. Selepas perendaman selama 72 jam, kecekapan perencatan adalah antara $60.48 \%$ pada suhu 319 K dan $73.81 \%$ pada suhu 298 K. Penjerapan ekstrak ke permukaan MS mengikuti penjerapan isoterma Langmuir manakala nilai tenaga bebas ( $\Delta$ Gads) menunjukkan ciri-ciri physisorption. Pembentukan lapisan pelindung pada permukaan besi telah disahkan melalui analisis SEM dan EDX. Hasil kajian ini telah menunjukkan potensi daun EG sebagai perencat kakisan keluli yang terdedah kepada persekitaran berasid.

Kata kunci: Keluli, Elaeis guineensis, perencatan kakisan, pengurangan berat, SEM
\end{abstract}

(C) 2018 Penerbit UTM Press. All rights reserved 


\subsection{INTRODUCTION}

According to numerous publications, the natural process of material corrosion has resulted in billions of dollarsworth of damage affecting a wide range of industries. Hence, it is a major cause of concern [1, 2, 3]. Because of its low cost and excellent mechanical properties, mild steel is frequently employed as a construction material in a broad range of industries [4]. Acid solutions are widely used in industry, the most important fields of acid solution applications are acid pickling, industrial acid cleaning, acid descaling and oil well acidizing $[5,6]$. The corrosion rate of metals in acidic environments is substantial, especially when the corrosion products are aqueous soluble. Consequently, research and analysis of corrosion inhibitors to protect against steel corrosion in acid solutions is significant for both academic and practical purposes [7].

In general, corrosion inhibitors added in small quantity over corrosive medium with the aim of reducing the rate of corrosion by a process of surface adsorption [8, 9]. Organic compounds with heteroatoms (e.g. sulphur, nitrogen, oxygen) / multiple bonds inhibit corrosion effectively even at low concentrations through adsorption mechanism [10, 11 , 12].

In spite of this effectiveness, the significant operating costs and detrimental environmental impacts of synthetic corrosion inhibitors mitigate against their everyday use for corrosion inhibition. As a consequence of the environmental issues, current research into corrosion inhibitors for metals in acidic conditions has concentrated more and more upon green (environmentally sound) inhibitors derived from plant extracts, with the aim of superseding the harmful substances presently employed $[13,14,15]$.

However, it has not been possible to identify any reports in the literature of corrosion inhibition use of $95 \%$ ethanol to extract of Elaeis guineensis. In contrast, $95 \%$ ethanol solvent used to dissolve all extractable materials from the plant which involve pigments, highly volatile aromatic molecules as well as non-aromatic waxes. Thus, the purpose of this work is to examine the inhibitory and adsorptive effects of Elaeis guineensis leaves extract using $95 \%$ ethanol at different temperatures to inhibit the corrosion of mild steel in 1 $\mathrm{M} \mathrm{HCl}$ medium.

In Malaysia, oil palm (Elaeis guineensis) is considered as an agricultural waste from oil palm plantation and currently, Malaysia is the second largest producer of palm oil in the world with the total planted area of 4.917 million hectares. Whilst oil palm finds a variety of uses in plywood manufacture [16], cooking oils [17], and other food items [18], as well as in pharmacology [19].

The corrosion inhibition mechanism by utilizing weight loss measurements at different temperatures was evaluated. The morphology and adsorption of the Elaeis guineensis inhibitor on the mild steel surface were investigated by SEM and EDX techniques.

\subsection{METHODOLOGY}

\subsection{Preparation of Elaeis Guineensis (EG) Inhibitor}

Fresh leaves specimens of oil palm (Elaeis guineensis) were collected from Universiti Teknologi Malaysia (UTM), Johor, Malaysia. The EG extraction was accomplished by rinsing the specimens under running tap water and allowed to dry in a shaded location. Dried leaves were subsequently powdered to size between 1-5 mm. $100 \mathrm{~g}$ of the resulting powder were immersed in $800 \mathrm{~mL}$ of analytical reagent grade $95 \%$ ethanol (Orec) for 15 days at room temperature. The suspension was then filtered through Whatman No.1 filtration paper and then subjected to Heating Mantle (MS-E105) to expel the ethanol extract as shown in Figure 1.

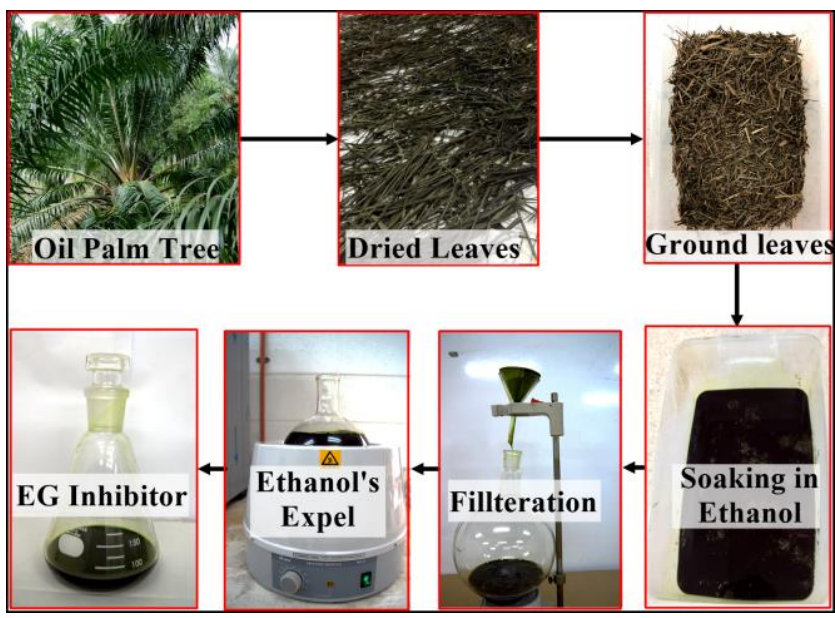

Figure 1 Preparation process of green corrosion inhibitor from Elaeis guineensis leaves

\subsection{Specimen Preparation}

The Faculty of Civil Engineering, UTM purchased the mild steel sheet. The sheet was subjected to pretreatment by cutting it mechanically into coupons with dimensions $30 \times 40 \times 10 \mathrm{~mm}$ and polished using emery papers of up to grade 1500 and then degreasing with acetone. The mild steel coupon was then rinsed with distilled water and air-dried prior to immersion in $1 \mathrm{M}$ $\mathrm{HCl}$. The mild steel coupon was analysed using GDS (Glow Discharge Spectrometer -Leco 850A) to obtain the chemical compositions of mild steel (wt.\%) which were as follows: $0.27 \% \mathrm{C}, 0.1 \% \mathrm{Mn}, 0.5 \% \mathrm{Si}, 0.06 \% \mathrm{P}$, $0.04 \% \mathrm{~S}$ and the remaining were Fe.

\subsection{Weight Loss Measurement}

In the most straightforward and standard corrosion assessment approach, weight loss measurement, a specimen of the mild steel coupon under study is exposed to a corrosive environment for a specific amount of time, at the end of which the specimen is removed and a weight loss measurement is taken. The 
corrosion rate is then defined as the amount of weight loss taking place over the exposure time [20].

Weight loss analyses were performed in uncovered beakers containing $50 \mathrm{~mL}$ of $1 \mathrm{M}$ (grade $37 \% \mathrm{HCl}$ ) in the presence and absence of different concentrations $(2.5,5,7.5$ and $10(\% \mathrm{v} / \mathrm{v}))$ of Elaeis guineensis extract. The solutions were allowed to stand for $72 \mathrm{~h}$ at temperature $298 \mathrm{~K} \pm 1$ (room temperature) and $319 \mathrm{~K} \pm$ 1. Following $72 \mathrm{~h}$ the mild steel coupons were removed, rinsed with distilled water and acetone, dried and weighed on an electronic balance (METTLER TOLEDO, ME204 model with sensitivity- $\pm 0.0001 \mathrm{~g})$. The difference in weight of the mild steel before and after exposure to the corrosive $\mathrm{HCl}$ acid environment indicated the mild steel weight loss. To ensure that dependable results were obtained, the tests were undertaken three times and the mean weight loss value was recorded (see Table 1). The inhibition efficiency $(n \%)$, corrosion rate $(C R)$ and surface coverage $(\theta)$ were determined using the equations below [21, 22]:

$$
\eta(\%)=\left(\frac{W_{o}^{-} W_{i}}{W_{o}}\right) \times 100
$$

whereby $W_{0}$ is the weight loss in the absence of Elaeis guineensis extract, and $W_{i}$ is the weight loss values in the presence of the inhibitor.

$$
C R(\mathrm{~mm} / \text { year })=\frac{87.6 \times W}{\rho A T}
$$

Whereby $W$ is the weight loss (mg) of the MS coupon, $\rho$ is the MS density $\left(\mathrm{g} \cdot \mathrm{cm}^{-3}\right), A$ is the MS surface area $\left(\mathrm{cm}^{2}\right)$ and $t$ is the reaction time allowed (h).

$$
\theta=\frac{\eta(\%)}{100}
$$

Table 1 Calculation of mild steel weight loss based on three attempts

\begin{tabular}{ccccc}
\hline $\begin{array}{c}\text { Inhibitor } \\
\text { concentration } \\
\text { \%(v/v) }\end{array}$ & $\begin{array}{c}\text { Weight } \\
\text { loss 1 } \\
\mathbf{( g )}\end{array}$ & $\begin{array}{c}\text { Weight } \\
\text { loss 2 } \\
\mathbf{( g )}\end{array}$ & $\begin{array}{c}\text { Weight } \\
\text { loss 3 } \\
\mathbf{( g )}\end{array}$ & $\begin{array}{c}\text { Average } \\
\text { Weight } \\
\text { loss } \mathbf{( g )}\end{array}$ \\
\hline Blank & 0.3877 & 0.3871 & 0.3868 & 0.3872 \\
2.5 & 0.1442 & 0.1432 & 0.1431 & 0.1435 \\
5.0 & 0.1317 & 0.1313 & 0.1312 & 0.1314 \\
7.5 & 0.1144 & 0.1138 & 0.1129 & 0.1137 \\
10 & 0.1019 & 0.1013 & 0.101 & 0.1014 \\
\hline
\end{tabular}

\subsection{SEM-EDX}

The morphologies of the MS surface measuring $(30 \times 40$ $\times$ 10) $\mathrm{mm}$ in the presence and absence of $10 \%(\mathrm{v} / \mathrm{V})$ EG inhibitor in $1 \mathrm{M} \mathrm{HCl}$ solution after 120 hours immersion at room temperature were investigated by scanning electron microscope (JEOL, JSM-IT300). The mild steel coupons were fixed on an aluminium stub using double-sided adhesive tape and subjected to the accelerating voltage of $5.0 \mathrm{kV}$. However, to detect the elemental composition of MS surface in the presence and absence of EG inhibitor in acidic medium, the analyser was fitted with Energy Dispersive $X$-Ray Analysis (EDX).

\subsection{RESULTS AND DISCUSSION}

\subsection{Weight Loss Measurement}

In the present study, weight loss measurements were used to assess the effect upon the corrosion of mild steel immersed for $72 \mathrm{~h}$ in $1 \mathrm{M} \mathrm{HCl}$ solution at $298 \mathrm{~K}$ and $319 \mathrm{~K}$ due to the addition of various concentrations of Elaeis guineensis extract $12.5 \%, 5 \%, 7.5 \%$ and $10 \%$ $(v / v))$. Anodic and cathodic dissolution of iron in acidic media can be represented by the following equations [23]:

$$
\begin{aligned}
& \mathrm{Fe} \rightarrow \mathrm{Fe}^{2+}+2 e^{-} \\
& 2 H^{+}+2 e^{-} \rightarrow H_{(a d s)} \rightarrow H_{2}
\end{aligned}
$$

As a consequence of these reactions, and the extremely soluble nature of the products resulting from the corrosion reactions, the mild steel loses weight in the acidic medium. In Tables (2 and 3), and Figures (2 and 3 ), the results are presented in terms of inhibitor efficiency, corrosion rate and surface coverage. Thus, the corrosion rate of mild steel decreased, and the inhibitor efficiency $(\% \eta)$ of Elaeis guineensis extract increased, with increasing inhibitor concentration. From Table 2 and Figure 2, it is seen that the maximum inhibitor efficiency $(73.81 \%)$, and minimum corrosion rate $(1.31 \mathrm{~mm} /$ year) were obtained at an inhibitor concentration of $10 \%(\mathrm{v} / \mathrm{v})$ and temperature at $298 \mathrm{~K}$. Furthermore, at the higher temperature of $319 \mathrm{~K}$, Table 3 and Figure 3 indicate that the inhibitor efficiency decreased to $60.48 \%$ and the corrosion rate of mild steel increased to $2.0 \mathrm{~mm} /$ year for the same inhibitor concentration. Increasing the concentration of inhibitor allows for increased presence of inhibitor at the metal-solution interface and enhanced adsorption of inhibitor onto the metal surface, hence providing greater surface coverage. Thus, increasing inhibitor concentration is linked to decreasing corrosion rate, due to an increased area of surface covered $(\theta)$ and to obstruction of the corrosion reaction sites by surface adsorption of the phytochemical components of Elaeis guineensis extract, effectively defending the metal surface from attack by the corrosive ions in the acidic environment. Hence, Elaeis guineensis extract is demonstrated to be an effective corrosion inhibitor for mild steel exposed to $1 \mathrm{M} \mathrm{HCl}$ solution. 
Table 2 Weight loss parameters of mild steel in the absence and presence of different concentrations of Elaeis guineensis extract in $1 \mathrm{M} \mathrm{HCl}$ at $298 \mathrm{~K}$ for $72 \mathrm{~h}$

\begin{tabular}{|c|c|c|c|c|}
\hline $\begin{array}{c}\text { Inhibitor } \\
\text { concentration } \\
\%(v / v)\end{array}$ & $\begin{array}{c}\text { Weight loss } \\
\text { (g) }\end{array}$ & $\begin{array}{c}\text { CR } \\
(\mathrm{mm} / \mathrm{y})\end{array}$ & $\eta(\%)$ & $(\theta)$ \\
\hline Blank & 0.3872 & 5.00 & 0.00 & 0.000 \\
\hline 2.5 & 0.1435 & 1.85 & 62.94 & 0.629 \\
\hline 5.0 & 0.1314 & 1.70 & 66.06 & 0.661 \\
\hline 7.5 & 0.1137 & 1.47 & 70.64 & 0.706 \\
\hline 10 & 0.1014 & 1.31 & 73.81 & 0.738 \\
\hline
\end{tabular}

Table 3 Weight loss parameters of mild steel in the absence and presence of different concentrations of Elaeis guineensis extract in $1 \mathrm{M} \mathrm{HCl}$ at $319 \mathrm{~K}$ for $72 \mathrm{~h}$

\begin{tabular}{|c|c|c|c|c|}
\hline $\begin{array}{c}\text { Inhibitor } \\
\text { concentration } \\
\%(v / v)\end{array}$ & $\begin{array}{l}\text { Weight loss } \\
\text { (g) }\end{array}$ & $\begin{array}{c}\text { CR } \\
(\mathrm{mm} / \mathrm{y})\end{array}$ & $\eta(\%)$ & $(\theta)$ \\
\hline Blank & 0.3907 & 5.05 & 0.00 & 0.000 \\
\hline 2.5 & 0.2056 & 2.66 & 47.38 & 0.474 \\
\hline 5.0 & 0.1827 & 2.36 & 53.24 & 0.532 \\
\hline 7.5 & 0.1693 & 2.19 & 56.67 & 0.567 \\
\hline 10 & 0.1544 & 2.00 & 60.48 & 0.629 \\
\hline
\end{tabular}

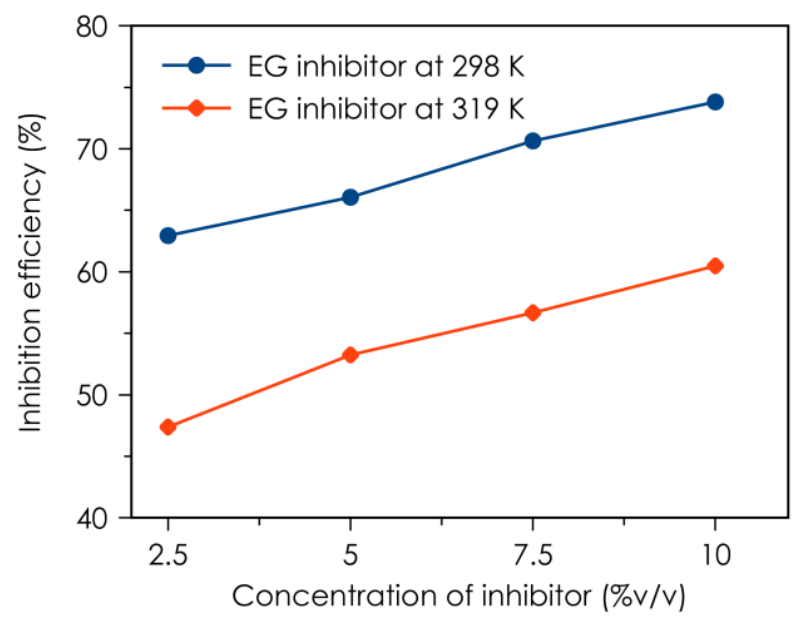

Figure 2 Inhibitor efficiency of mild steel coupons in the presence of Elaeis guineensis extract in $1 \mathrm{M} \mathrm{HCl}$ at different temperatures

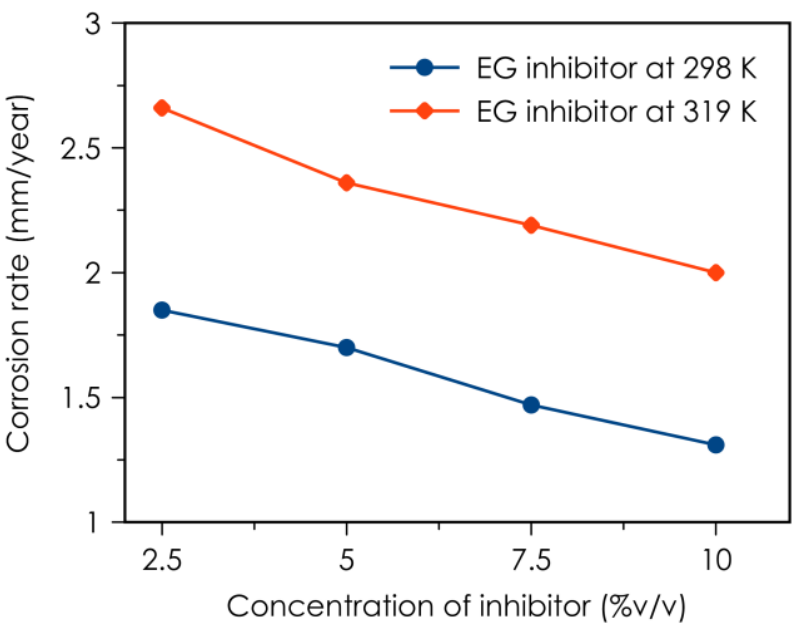

Figure 3 Corrosion rate of mild steel coupons in the presence of Elaeis guineensis extract in $1 \mathrm{M} \mathrm{HCl}$ at different temperatures

\subsection{Adsorption Isotherm}

Adsorption isotherms can provide information on the relationship between the inhibitor molecules and the surface of mild steel coupon. The degree of surface coverage $(\theta)$ determined from the weight loss measurement was utilized to assess the best fit isotherm curve for the data. The correlation coefficient resulting from the Langmuir adsorption isotherms graph was utilized to identify the the most relevant isotherms to the test data produced [24].

Table 2 and 3 indicate that there is an obvious increase in the rate of efficiency in the presence of increased EG extract as a consequence of a higher proportion of mild steel surface coverage resulting from enhanced adsorption of this inhibitor molecules. The Langmuir adsorption isotherms assumptions may be described as follows [25]:

$$
\frac{C}{\theta}=\frac{1}{K_{(a d s)}}+C
$$

whereby $C$ is the inhibitor concentration, $\theta$ is the degree of surface area coverage, and $K$ is the adsorption equilibrium constant.

Figure 4 depicts that a logarithmic graph of $(C / \theta$ against $C$ ) gives rise to straight lines and demonstrate a Langmuir adsorption isotherm for the adsorption of $95 \%$ ethanol from Elaeis guineensis on the mild steel coupon surface. The Langmuir isotherm indicates that the $R^{2}$ is close to unity and this may be explained because of molecular interaction between inhibitor molecules and the MS coupon surface. The investigation demonstrates that the gradients of the slopes for weight loss was 0.959 at $298 \mathrm{~K}$ and 0.947 at $319 \mathrm{~K}$, this is indicative of adsorption of Elaeis guineensis inhibitor on the mild steel surface at different temperatures obeys Langmuir adsorption isotherm in $1 \mathrm{M} \mathrm{HCl}$ medium. 


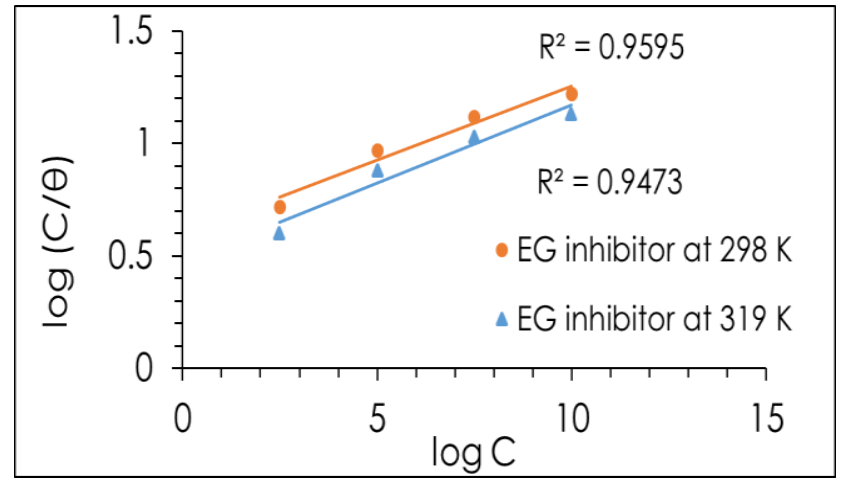

Figure 4 Adsorption of Elaeis guineensis extract in $1 \mathrm{M} \mathrm{HCl}$ at different temperatures by Langmuir adsorption isotherm plot

\subsection{Free Energy Calculation}

The equilibrium constant of adsorption (Kads) was used to calculate the free energies of adsorption ( $\Delta$ Gads) according to the following equation [26]:

$$
\Delta G_{a d s}=-R T \times \ln \left(55.5 K_{a d s}\right)
$$

whereby, $\mathrm{R}$ is the gas constant $(8.314 \mathrm{~J} / \mathrm{mol} . \mathrm{K}), \mathrm{T}$ is the absolute temperature $(\mathrm{K})$, and the constant 55.5 is the molar concentration of water in the solution (M). The calculated values of $\mathrm{Kads}$ and $\Delta \mathrm{Gads}$ are presented in Table 4. In general, larger Kads values are linked with an enhanced propensity to adsorb onto the mild steel surface, while negative values for $\Delta$ Gads indicate the spontaneity and stability of the adsorption process. Further, $\Delta$ Gads values of up to $-20 \mathrm{~kJ} \mathrm{~mol}^{-1}$ are generally indicative of physical adsorption due to electrostatic interaction between charged inhibitor molecules and the mild steel surface, while $\Delta$ Gads values greater than $-20 \mathrm{~kJ} \mathrm{~mol}^{-1}$ suggest chemisorption by the transfer or sharing of charge between the inhibitor molecule and the mild steel surface to form a coordinate bond [27, 28]. Thus, from Table 4, the calculated values of $\Delta$ Gads in acid solution, specifically $-11.67 \mathrm{~kJ} \mathrm{~mol}^{-1}$ at $298 \mathrm{~K}$ and $-12.77 \mathrm{~kJ} \mathrm{~mol}^{-1}$ at $319 \mathrm{~K}$, demonstrate physical adsorption of the EG extract onto the mild steel surface.

Table 4 Free energy values of Elaeis guineensis extract at different temperatures.

\begin{tabular}{cccc}
\hline Temperature & $\mathbf{R}^{\mathbf{2}}$ & $\mathbf{K}_{\text {ads }}$ & $\Delta \mathbf{G}_{\text {ads }}(\mathrm{kJ} / \mathrm{mol})$ \\
\hline $298 \mathrm{~K}$ & 0.9595 & 2.00 & -11.67 \\
$319 \mathrm{~K}$ & 0.9473 & 2.22 & -12.77 \\
\hline
\end{tabular}

\subsection{Temperature Effects}

Since temperature is a significant factor in the metal dissolution process, the effect of temperature upon the corrosion and corrosion inhibition of mild steel in $1 \mathrm{M}$
$\mathrm{HCl}$ solution, in the presence and absence of various concentrations of the EG inhibitor, was examined by weight loss measurements after immersion at $298 \mathrm{~K}$ and $319 \mathrm{~K}$. The results presented in Table 2 and 3 demonstrate an increase in corrosion rate with increasing temperature both in the presence and absence of inhibitor, while inhibition efficiency is seen to decrease with increasing temperature. According to the literature, this increase in corrosion rate can be explained by desorption of the adsorbed EG molecules from the mild steel surface at the higher temperature [29]. Adsorption of corrosion inhibitors at the metal/solution interface results from the formation of either electrostatic or covalent bonds between the inhibitor molecule and the metal surface atoms [30]. Further, since the corrosion of metals in an acidic environment usually involves the evolution of $\mathrm{H}_{2}$ gas, an increase in temperature will accelerate the rate of metal dissolution. Hence, the corrosion reaction [23], impairs physical adsorption of the inhibitor species onto the mild steel surface. Thus, the corrosion protection mechanism depends upon the adsorption behaviour of the corrosion inhibitor which, as with organo-electrochemical reactions in general, is defined by the adsorption isotherm. Thus, the adsorptive behaviour of the corrosion inhibitor is a central aspect of the present investigation, providing significant evidence regarding the nature of the interactions between the metal and the inhibitor, which are driven by the adsorption isotherm. The results of the present investigation at $298 \mathrm{~K}$ and $319 \mathrm{~K}$ indicated that the mechanism of adsorption of Elaeis guineensis extract onto the mild steel surface is best described by the Langmuir adsorption isotherm.

\subsection{SEM Analysis}

Figure 5 presents the SEM micrographs of the mild steel surface following $120 \mathrm{~h}$ of immersion. Figure $5 \mathrm{a}$ shows the damaged surface morphology due to immersion of mild steel in $1 \mathrm{M} \mathrm{HCl}$ in the absence of EG inhibitor, while Figure $5 b$ shows a notably improved surface morphology in the presence of EG, revealing a significant reduction in corrosion. This is explained by effective deposition of inhibitor molecules onto the surface of the mild steel to form a functional protective film. This provides further evidence that the EG extract behaves as a corrosion inhibitor for mild steel due to an adsorption process. 

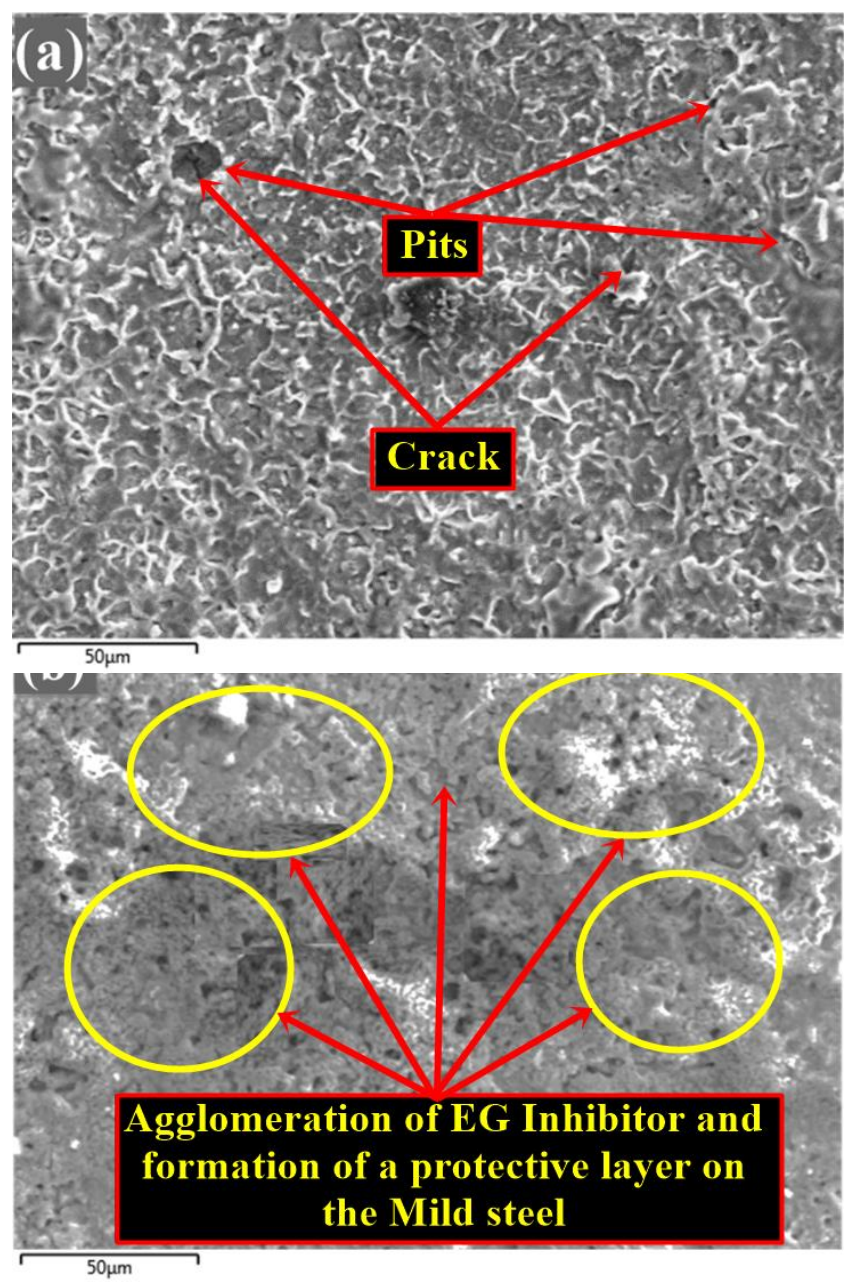

Figure 5 Scan Electron Microscope (SEM) For mild steel surface following Immersion for $120 \mathrm{~h}$ in (a) $1 \mathrm{M} \mathrm{HCl}$ and (b) 1 $\mathrm{M} \mathrm{HCl}$ With EG Inhibitor

\subsection{EDX Analysis}

Figure 6 presents the EDX spectra of the mild steel surface after $120 \mathrm{~h}$ of immersion in the presence and absence of $10 \%(\mathrm{v} / \mathrm{v})$ of EG inhibitor. In the absence of inhibitor (Figure 6a and Table 5), the only signals observed in the spectrum are for carbon (C) and high percentage of iron $(\mathrm{Fe})$ and oxygen (O). These are indicative of the formation of hydrated oxide (rust). While, in the presence of inhibitor (Figure $6 \mathrm{~b}$ and Table $5)$, characteristic signals for nitrogen $(N)$ and oxygen (O) are also present. An interesting point in this study is the significant decrease for $\mathrm{Cl}$ ions from $11.6 \%$ to $1.5 \%$ in the presence of EG inhibitor. The existence of signals for $\mathrm{N}$ and $\mathrm{O}$ in the spectrum supports the hypothesis that EG acts as a corrosion inhibitor for mild steel by adsorbing onto the steel surface.
Table 5 EDX elements for MS in the presence and absence of $10 \%$ of $\mathrm{EG}$ inhibitor in $1 \mathrm{M} \mathrm{HCl}$

\begin{tabular}{llllllll}
\hline \multirow{2}{*}{ Specimen } & \multicolumn{9}{l}{ Composition (\%) } & Fe & C & O & Cu & Si & Cl & N \\
\hline Blank & 69.3 & 5.8 & 11.7 & 1.5 & 0.1 & 11.6 & 0 \\
EG & 41.5 & 27.4 & 11.1 & 0.5 & 0.1 & 1.5 & 17.9 \\
\hline
\end{tabular}
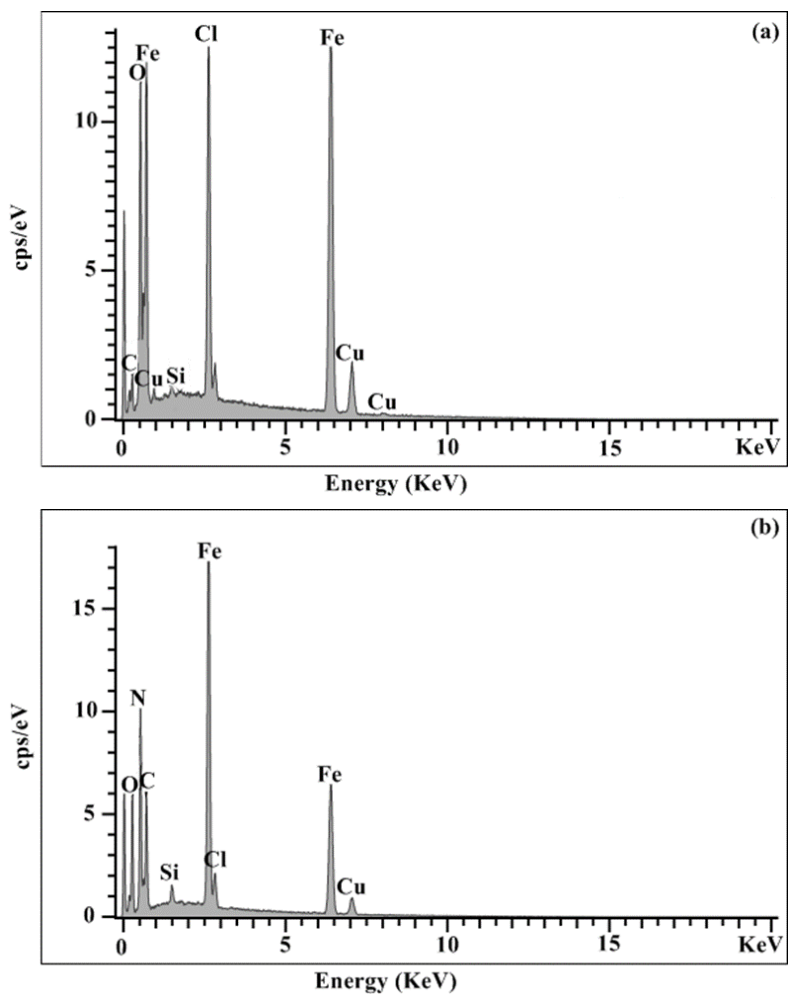

Figure 6 Energy Dispersive X-Ray Analysis (EDX) For mild steel surface following Immersion for $120 \mathrm{~h}$ in (a) $1 \mathrm{M} \mathrm{HCl}$ and (b) 1 $\mathrm{M} \mathrm{HCl}$ With EG Inhibitor

\subsection{CONCLUSION}

Corrosion of mild steel in $1 \mathrm{M} \mathrm{HCl}$ was effectively inhibited by EG extract, due to the formation of a protective barrier layer. The inhibition efficiency and degree of surface coverage of the mild steel in acidic medium were shown to increase with increasing concentration of inhibitor and decrease with increasing temperature. The inhibition efficiency of EG inhibitor reached $73.81 \%$ and $60.48 \%$ after $72 \mathrm{~h}$ of immersion in $1 \mathrm{M} \mathrm{HCl}$ medium at temperatures of $298 \mathrm{~K}$ and $319 \mathrm{~K}$ respectively. The adsorption behaviour of the inhibitor in the acidic environment was shown to correspond to the Langmuir adsorption isotherm, with negative values of $\Delta$ Gads indicating a spontaneous adsorption process. The adsorption of EG molecules onto the mild steel surface was supported by SEM and EDX analysis. The present study demonstrates that adsorption of EG onto the mild steel surface results in reduced corrosion in acidic media, hence EG extract can be regarded as an efficient, economical, 
biodegradable, and environmentally sound corrosion inhibitor for mild steel in acid media.

\section{Acknowledgement}

The authors gratefully acknowledge the support given to this research by the Ministry of Science and Technology Malaysia under Grant No. 45090, the Ministry of Higher Education under Grant No. 4F528, and the Research Management Centre and Technician Staff of Faculty of Civil Engineering, Universiti Teknologi Malaysia.

\section{References}

[1] Helen L., Rahim A., Saad B., Saleh M. and Raja P. B. 2014. Aquilaria Crassna Leaves Extracts - A Green Corrosion Inhibitor for Mild Steel in $1 \mathrm{M} \mathrm{HCl}$ Medium. International Journal of Electrochemical Science. 9: 830-846.

[2] De Baere K., Verstraelen H., Rigo P., Van Passel S., Lenaerts S. and Potters G. 2013. Reducing the Cost of Ballast Tank Corrosion: An Economic Modeling Approach. Marine Structures. 32: 136-152.

[3] Jiang G., Keller J., Bond P. L. and Yuan Z. 2016. Predicting Concrete Corrosion of Sewers Using Artificial Neural Network. Water Research. 92: 52-60.

[4] Amin, M. A. and Ibrahim, M. M. 2011. Corrosion and Corrosion Control of Mild Steel in Concentrated $\mathrm{H}_{2} \mathrm{SO}_{4}$ Solutions by a Newly Synthesized Glycine Derivative. Corrosion Science. 53: 873-885.

[5] Garai, S., Garai, S., Jaisankar, P., Singh, J. K. and Elango, A. 2012. A Comprehensive Study on Crude Methanolic Extract of Artemisia Pallensb (Asteraceae) and Its Active Component as Effective Corrosion Inhibitors of Mild Steel in Acid Solution. Corrosion Science. 60: 193-204.

[6] Banerjee, S., Srivastava, V. and Singh, M. M. 2012. Chemically Modified Natural Polysaccharide as Green Corrosion Inhibitor for Mild Steel in Acidic Medium. Corrosion Science. 59: 35-41.

[7] Raja P. B., Qureshi A. K., Rahim A. A., Osman H. and Awang K. 2013. Neolamarckia Cadamba Alkaloids as Eco-Friendly Corrosion Inhibitors for Mild Steel In $1 \mathrm{M} \mathrm{HCl}$ Media. Corrosion Science. 69: 292-301.

[8] Benali, O., Benmehdi, H., Hasnaoui, O., Selles, C. and Salghi, R. 2013. Green Corrosion Inhibitor: Inhibitive Action of Tannin Extract of Chamaerops Humilis Plant for the Corrosion of Mild Steel in $0.5 \mathrm{M} \mathrm{H}_{2} \mathrm{SO}_{4}$. Journal of Materials and Environmental Science. 4 (1): 127-138.

[9] Abdulrahman A., Ismail M., Hussain M. S. 2011. Inhibition of Corrosion of Mild Steel in Hydrochloric Acid by Bambusa Arundinacea. International Review of Mechanical Engineering. 5(1): 59-63.

[10] Asaad, M. A., Ismail, M., Raja P. B. and Khalid, N. H. A. 2018 Rhizophora Apiculata as Eco-Friendly Inhibitor against Mild Steel Corrosion in $1 \mathrm{M} \mathrm{HCl}$. Surface Review and Letters. 24(8): 1-11.

[11] Mehdipour, M., Ramezanzadeh, B. and Arman, S. Y. 2015 Electrochemical Noise Investigation of Aloe Plant Extract as Green Inhibitor on the Corrosion of Stainless Steel in $1 \mathrm{M}$ $\mathrm{H} 2 \mathrm{SO}$ 4. Journal of Industrial and Engineering Chemistry. 21: 318-327.

[12] Asaad, M. A., Sarbini, N. N., Sulaiman. A., Ismail, M., Huseien. G. F., Majid. Z. A. and Raja P. B. 2018. Improved Corrosion Resistance of Mild Steel Against Acid Activation: Impact of Novel Elaeis Guineensis and Silver Nanoparticles. Journal of Industrial and Engineering Chemistry. 63: 139-148.

[13] Zulkiflia, F., Alia, N., Sukeri, M., Yusof, M., Isa, M. I. N., Yabuki, A. and W.B. Wan Nika, W. B. W. 2017. Henna Leaves Extract as a Corrosion Inhibitor in Acrylic Resin Coating. Progress in Organic Coatings. 105: 310-319.

[14] Ituen, E., Akaranta, O., James, A. and Sun, S. 2017. Green and Sustainable Local Biomaterials for Oilfield Chemicals: Griffonia Simplicifolia Extract as Steel Corrosion Inhibitor in Hydrochloric Acid. Sustainable Materials and Technologies. 11: 12-18.

[15] El-Etre, A. Y., Ali, A. I. 2017. A Novel Green Inhibitor for CSteel Corrosion in $2.0 \mathrm{Mol} \mathrm{L}^{-1}$ Hydrochloric Acid Solution. Chinese Journal of Chemical Engineering. 25: 373-380.

[16] Szymona, K., Borysiuk, P., San H'ng, P., Chin, K. L. and Mamiński, M. 2014. Valorization of Waste Oil Palm (Elaeis Guineensis Jaca.) Biomass through Furfurylation. Materials \& Design. 53: 425-429.

[17] Chang, S. K., Ismail, A., Yanagita, T., Esa, N. M. and Baharuldin, M. T. H. 2015. Antioxidant Peptides Purified and Identified from the Oil Palm (Elaeis Guineensis Jacq.) Kernel Protein Hydrolysate. Journal of Functional Foods. 14: 63-75.

[18] Kok, S., Ong-Abdullah, M., Ee, G. C. and Namasivayam, P. 2011. Comparison of Nutrient Composition in Kernel of Tenera and Clonal Materials of Oil Palm (Elaeis Guineensis Jacq.) Food Chemistry. 12: 91343-1347.

[19] Soundararajan, V. and Sreenivasan, S. 2012. Antioxidant Activity of Elaeis Guineensis Leaf Extract: An Alternative Nutraceutical Approach in Impeding Aging. APCBEE Procedia. 2: 153-159.

[20] Bhawsar, J., Jain, P. K. and Jain, P. 2015. Experimental and Computational Studies of Nicotiana Tabacum Leaves Extract as Green Corrosion Inhibitor for Mild Steel in Acidic Medium. Alexandria Engineering Journal. 54: 769-775.

[21] Abiola, O. K. and Tobun Y. 2010. Cocos Nucifera L. Water as Green Corrosion Inhibitor for Acid Corrosion of Aluminium in $\mathrm{HCl}$ Solution. Chinese Chemical Letters. 21: 1449-1452.

[22] Eyu, D. G., Esah, H., Chukwuekezie, C., Idris, J. and Ismail, M. 2013. Effect of Green Inhibitor on the Corrosion Behaviour of Reinforced Carbon Steel in Concrete. ARPN Journal of Engineering and Applied Sciences. 8(5): 326-332.

[23] Solomon, M. M., Umoren, S. A., Udosoro, I. I. and Udoh, A. P. 2010. Inhibitive and Adsorption Behaviour of Carboxymethyl Cellulose on Mild Steel Corrosion in Sulphuric Acid Solution. Corrosion Science. 52: 1317-1325.

[24] Alaneme K. K., Olusegun, S. J. and Adelowo, O. T. 2016. Corrosion Inhibition and Adsorption Mechanism Studies of Hunteria Umbellata Seed Husk Extracts on Mild Steel Immersed in Acidic Solutions. Alexandria Engineering Journal. 55: 673-681.

[25] ALI, S. M. and Al LEHAIBI, H. A. 2016. Control of Zinc Corrosion in Acidic Media: Green Fenugreek Inhibitor. Transactions of Nonferrous Metals Society of China. 26: 3034-3045.

[26] Odewunmi, N., Umoren, S. and Gasem, Z. 2015. Utilization of Watermelon Rind Extract as a Green Corrosion Inhibitor for Mild Steel in Acidic Media, Journal of Industrial and Engineering Chemistry. 21: 239-247.

[27] Abu-Dalo, M. A., Al-Rawashdeh, N. A. and Mutlaq. A. A. 2016. Green Approach to Corrosion Inhibition of Mild Steel by Lignin Sulfonate in Acidic Media. Journal of Iron and Steel Research, International. 23: 722-732.

[28] Kowsari, E., Payami, M., Amini, R., Ramezanzadeh, B. and Javanbakht, M. Task-Specific lonic Liquid as A New Green Inhibitor of Mild Steel Corrosion. Applied Surface Science. 289: 478-486.

[29] Verma, C., Singh, P. and Quraishi, M. A. 2016. A Thermodynamical, Electrochemical and Surface Investigation of Bis (Indolyl) Methanes as Green Corrosion Inhibitors for Mild Steel in $1 \mathrm{M}$ Hydrochloric Acid Solution. Journal of the Association of Arab Universities for Basic and Applied Sciences. 21: 24-30.

[30] Hussin, M. H. and Kassim, M. J. 2011. The Corrosion Inhibition and Adsorption Behavior of Uncaria Gambir Extract on Mild Steel in $1 \mathrm{M} \mathrm{HCl}$. Materials Chemistry and Physics. 125: 461468. 